\title{
SECTION 6 OF THE BILL OF RIGHTS ACT 1990: A CASE FOR PARLIAMENTARY RESPONSIBILITY FOR HUMAN RIGHTS AND FREEDOMS
}

\author{
Jan Stemplewitz ${ }^{*}$
}

The author addresses the role of the Courts in considering whether delegated legislation is ultra vires by reason of breaching the New Zealand Bill of Rights Act 1990. He suggests that such review should not consider whether the limitation in any such regulation is justifiable in a free and democratic society, but ought to only consider if it infringes rights and freedoms contained in the Bill of Rights Act. In his view, not only would such an approach result in much delegated legislation being held to be ultra vires, but that it would force Parliament to take responsibility for the rights guaranteed by the Bill of Rights Act by closely considering them when enacting provisions which permit delegated legislation.

\section{INTRODUCTION}

This article might be somewhat unusual: Some may find the propositions advanced in it to be quite radical, others might regard them as revolutionary (whether in a positive or negative way). History, however, has shown that words such as "radical" and "revolutionary" are often relative terms depending on what is generally accepted at a certain point in time. To this, the history of law poses no exception. In one of his last judgments before retiring from the position of Law Lord in the House of Lords, Lord Cooke of Thorndon expressed the view that: ${ }^{1}$

... the day will come when it will be more widely recognised that Associated Provincial Picture

Houses Ltd $v$ Wednesbury Corporation [1948] 1 KB 223 was an unfortunately retrogressive

* Submitted for the LLM Degree at Victoria University of Wellington.

$1 R v$ Secretary for the Home Department, Ex parte Daly [2001] UKHL 26, 33 (HL) Lord Cooke. 
decision in English administrative law, insofar as it suggested that there are degrees of unreasonableness and that only a very extreme degree can bring an administrative decision within the legitimate scope of judicial invalidation.

Ten years ago, challenging the traditional Wednesbury grounds of judicial review would have probably been considered "revolutionary" to say the least.

The underlying theory of this paper is that ultimately Parliament, and not the executive branch of Government or a subordinate legislative body, should be responsible for dealing with issues involving fundamental human rights and freedoms. After highlighting the general recognition of this theory in the United Kingdom and Germany, the paper will demonstrate that first indications of its acceptance in New Zealand can be found in the case law, however, there are still examples where fundamental rights and freedom are restricted without an adequate involvement of the legislature. The paper will then develop a possible approach to redress this situation using section 6 of the New Zealand Bill of Rights Act 1990 (Bill of Rights Act).

\section{PARLIAMENTARY RESPONSIBILITY FOR RIGHTS AND FREEDOMS}

It has long been recognised in modern democracies that Parliament, as the highest body of representatives, not only exercises powers derived from the will of the people but also is ultimately accountable to the people and responsible for exercising those powers. However, it is equally accepted that in today's complex world not every single matter can be regulated in great detail by the legislature itself. Parliament simply does not have the time, resources, and expertise to fully formulate every rule that governs a certain subject matter. Regulations, or subordinate legislation in general, made by such bodies that are familiar with the specific subject-matter are necessary both for reasons of efficiency as well as effectiveness of the law. This does not, however, relieve Parliament of its responsibility to properly "instruct" those bodies as to what it wishes them to do. Otherwise it could be argued that specific regulations based on overly broad empowering sections cannot be traced back to a specific expression of the will of the people and are therefore not fully "prescribed by law" or, in other words, not in compliance with the rule of law. In the context of fundamental human rights, a principle of parliamentary responsibility consequently requires that any limitation itself must be sufficiently provided for by the legislature and that only the prescription of "details" may be delegated to other bodies.

\section{A The Principle in the United Kingdom and Germany}

\section{United Kingdom}

Where fundamental rights are at stake, the courts in the United Kingdom have been generally unwilling to allow the executive to make decisions or regulations that adversely 
affect those rights unless Parliament clearly empowered it to do so. As Lord BrowneWilkinson stated in $R v$ Secretary of State for the Home Department, Ex parte Pierson: ${ }^{2}$

From these authorities I think the following proposition is established. A power conferred by Parliament in general terms is not to be taken to authorise the doing of acts by the donee of the power which adversely affect the legal rights of the citizen or the basic principles on which the law of the United Kingdom is based unless the statute conferring the power makes it clear that such was the intention of Parliament.

The proposition has been affirmed in a number of subsequent decisions of the House of Lords, ${ }^{3}$ which held that various rules by the Home Secretary concerning, for example, the systematic examination of legal correspondence of prisoners were ultra vires with regards to the empowering provision. ${ }^{4}$ Whereas in most of these cases the issue was whether the empowering provision still allowed the extent of certain limitations imposed by the rules, the House of Lords in Raymond $v$ Honey $^{5}$ decided that the wording of the empowering provision was insufficient per se to authorise a rule that allowed the blocking of a prisoner's application to a court. ${ }^{6}$ Lord Wilberforce pointed out that "under English law, a convicted prisoner, in spite of his imprisonment, retains all civil rights which are not taken away expressly or by necessary implication". ${ }^{7}$

\section{Germany}

A similar, even stricter, principle has been developed by the German Federal Constitutional Court in its decision regarding the validity of regulations that prohibited medical practitioners with a special area of practice (eg neurologist, cardiologist etc) to also practice as a general practitioner. ${ }^{8}$ The Court - having the power to strike down legislation - not only found the regulations limiting the guaranteed freedom to choose and exercise

$2 \quad R v$ Secretary of State for the Home Department, Ex parte Pierson [1998] AC 539, 575 (HL) Lord Browne-Wilkinson.

3 See for example $R v$ Secretary of State for the Home Department, Ex parte Anderson [1984] QB 778 (CA); $R v$ Secretary for the Home Department, Ex parte Simms [1999] 3 WLR 328, 341 (HL) Lord Hoffmann; and Ex parte Daly, above. See also earlier decisions in: $R v$ Board of Visitors of Hull Prison, Ex parte St Germain [1979] QB 425 (CA); and Raymond v Honey [1983] 1 AC 1 (HL).

4 Section 47(1) of the Prison Act (UK) 1952 empowers the Secretary of State to make rules for the regulation of prisons and for the discipline and control of prisoners.

5 Raymond, above.

6 See, the Prison Act (UK) 1952, s 47(1).

7 Raymond, above, 10, Lord Wilberforce.

8 BVerfGE, volume 33, 125 (9 May 1972). BVerfGE reports decisions of the Federal Constitutional Court. 
one's profession to be unconstitutional, it also held that the legislature was required to regulate matters relating to medical practitioners itself. The Court enuciated a "principle of substantiality" which demands that any substantial issue relating to society must in substantial terms be dealt with by the legislature and not completely by way of regulations. ${ }^{9}$

\section{B The Principle in New Zealand}

At first sight, New Zealand appears to be in line with the European jurisprudence. Elias CJ recently expressed the view in Ngati Apa Ki Te Waipounamu Trust $v$ R that: ${ }^{10}$

[s] uch basic rights [as affirmed by the Bill of Rights] cannot be overridden by general or ambiguous words in a statute: $R v$ Secretary for the Home Department, ex parte Simms [1999] 3 WLR 328 (HL) at $\mathrm{p} 341$ per Lord Hoffmann; R v Secretary of State for the Home Department, ex parte Pierson [1998] AC 539 at p 575 per Lord Browne-Wilkinson. The principle of legality, recognised by the common law, has been expressly enacted by s 6 of the New Zealand Bill of Rights Act 1990.

Similarly, in Jeffcoat $v$ Waetford, Hammond J stated that: ${ }^{11}$

[a]ny intrusion into those rights [affirmed by the Bill of Rights] would clearly require explicit statutory authorisation, and even then the words actually used will be read very strictly, and wherever possible consistently with the New Zealand Bill of Rights Act 1990.

While both decisions did not concern the validity of subordinate legislation, it seems plausible that the New Zealand judiciary could apply those principles to declare ultra vires such subordinate legislation which infringes fundamental rights and freedoms without a clear and explicit statutory basis. Considering the supremacy of the New Zealand Parliament, such declarations by the courts would probably be regarded as enjoining the respective body from making subordinate legislation that is ultra vires rather than requiring Parliament to pass more explicit empowering legislation. ${ }^{12}$ In the end, the result would be the same: The legislature would need to concern itself with the respective issue - either by

9 See also an earlier decision to a similar effect in BVerfGE, volume 33, 1 (14 March 1972) and subsequent decisions in BVerfGE, volume 34, 165, 192 (6 December 1972); BverfGE, volume 49, 89, 126 (8 August 1978); BverfGE, volume 61, 260, 275 (20 October 1982); and BVerfGE, volume 88, 103, 116 (2 March 1993).

10 Ngati Apa Ki Te Waipounamu Trust v R [2000] 2 NZLR 659, 712 (CA) Elias CJ.

11 Jeffcoat $v$ Waetford (1999) 17 CRNZ 75, 76 (HC) Hammond J.

12 The same applies for the United Kingdom. Given the fact that the German Federal Constitutional Court can strike down any legislation (primary and subordinate) found to be unconstitutional, the "principle of substantiality" can be seen as being directed more towards the legislature not to delegate certain matters. 
regulating it directly through primary legislation or by enacting more specific empowering provisions.

And indeed, the recent decision of the Court of Appeal in Drew $v$ The Attorney-General and the Visiting Justice goes somewhat in that direction. ${ }^{13}$ The Court of Appeal struck down a regulation ${ }^{14}$ denying legal representation to prisoners in disciplinary hearings, as ultra vires to the respective empowering provision. ${ }^{15}$ Justice Blanchard came to the conclusion that the relevant empowering provision: ${ }^{16}$

... cannot have been intended by Parliament to authorise the making of a regulation which, in

its operative effect, results in some hearings which may be conducted in a manner contrary to

the principles of natural justice.

The Court of Appeal reached its conclusion by applying common law principles of construction, guided by the principles of natural justice. It found "no need to refer to the guarantee of the observance of those principles in section 27 of the Bill of Rights".17 However, speaking obiter dictum, Justice Blanchard pointed out that the Court was giving the empowering provision a meaning consistent with the rights and freedoms contained in the Bill of Rights (as mandated by section 6 of the Bill of Rights) and that this meaning did not authorise the regulation.

\section{The Apparent Non-Application of the Principle}

Despite the Drew decision, the principle referred to by Elias CJ and Hammond J seems to be applied half-heartedly at best in respect of subordinate legislation which restricts fundamental rights and freedoms based on broad empowering provisions. When analysing the Drew judgment, it becomes evident that the Court struck down the regulation because it always denied legal representation to an inmate regardless of the seriousness of a disciplinary charge or the complexity of the case. From this it can be inferred that the Court of Appeal would have upheld the regulation if it had had a less sweeping effect. However, even if the regulation had contained some balancing factors or exceptions, the empowering provision nevertheless simply did not provide for any

13 Drew $v$ The Attorney-General and the Visiting Justice [2002] 1 NZLR 58 (CA).

14 The regulation struck down was Regulation 144 of the Penal Institutions Regulations 1999.

15 The Penal Institutions Act (NZ) 1954, s 45(1)(19).

16 Drew, above, 73, Blanchard J.

17 Drew, above. 
"explicit statutory authorisation" to impinge ${ }^{18}$ - whether in a balancing or sweeping fashion - on the right to legal representation.

Another good example for the apparent non-application of the principle outlined above is the right to freedom of peaceful assembly and how it is limited. Section 16 of the Bill of Rights Act provides rather succinctly:

\section{Freedom of peaceful assembly -}

Everyone has the right to freedom of peaceful assembly.

One of the major limitations of this right can be found in various city or district council bylaws. These bylaws generally require a permit to be obtained prior to organising or conducting any form of assembly in a public place. The permit can be declined for a number of reasons. By way of example, the Wellington City Council Consolidated Bylaw 1991 sets out the following:

\section{MEETINGS AND PROCESSIONS ON ROADS}

17.10.1 No person shall without the prior written authority of the Council or the City Traffic Engineer:

Take part, on any road, in any assembly or combine with other persons in such a way as to impede pedestrian or vehicular traffic thereon, or to prevent or hinder ready access to shops or premises facing on the road; or

Make any public address or organise or conduct any public meeting, gathering, or demonstration, or attempt to organise or gather together a crowd, on any road; or

Except with such consent as aforesaid, no person shall hold organise or take part in any parade or procession whether in vehicles or on foot on any road.

17.10.2 In determining whether to grant or withhold permission as aforesaid the Council or the City Traffic Engineer shall have regard:

(a) To conditions of Traffic movement, both vehicular and pedestrian, at the time of the proposed assembly or procession, but

(b) To the likelihood of danger to life or property, or the likelihood of undue public disorder being caused or attracted by the proposed activity.

(c) To whether the proposed activity will cause unreasonable annoyance or inconvenience to other road users or to people living and working in the vicinity.

18 Jeffcoat $v$ Waetford (1999) 17 CRNZ 75, 76 (HC) Hammond J. 
As with any bylaw, the aforementioned provisions must be based on a proper empowering Act of Parliament in order to be valid. In this case the permit requirement limiting the right to freedom of assembly is based on the Local Government Act 1974. Section 684(1) of this Act allows councils to make bylaws for a number of purposes including:

(8) Conserving public health, wellbeing, safety, and convenience, and regulating drainage and sanitation:

(9) Regulating, controlling, or prohibiting the making of noise -

(a) In roads or public places; or

(b) In or upon land or buildings -

where such noise is likely to cause nuisance or annoyance to persons in any road or public place or residing in the vicinity of any road or public place or in the vicinity of that land or those buildings:

(13) Concerning roads and cycle tracks and the use thereof, and the construction of anything upon, over, or under a road or cycle track:

(30) Regulating the use of any reserve, recreation ground or other land or public place vested in the Council or under control of the Council.

These four items are the most "explicit" empowering provisions in the Local Government Act 1974 relied upon for limiting the right to freedom of peaceful assembly. None of the provisions expressly mentions the power to regulate public assemblies, and it seems doubtful that the power to impose such specific restrictions as contained in the Wellington City Council Bylaw could be inferred from such broad terms.

So if, as in this case, there is no "explicit statutory authorisation" (which Hammond J required) ${ }^{19}$ but only an empowering provision consisting of "general words" (which Elias CJ rejected), ${ }^{20}$ does section 6 of the Bill of Rights Act not mandate that the empowering provision is interpreted in a way which disallows any limitation by way of subordinate legislation? As the following part will attempt to demonstrate, the inability, or rather

19 Jeffcoat $v$ Waetford (1999) 17 CRNZ 75, 76 (HC) Hammond J.

20 Ngati Apa Ki Te Waipounamu Trust v R [2000] 2 NZLR 659, 712 (CA) Elias CJ. 
unwillingness, to utilise section 6 for such an interpretation largely derives from the way section 6, itself, is interpreted.

\section{GENERAL UNDERSTANDING OF THE MEANING OF SECTION 6}

\section{A Understanding of Section 6}

Section 6 of the Bill of Rights Act sets out a "rule of interpretation" which provides: ${ }^{21}$

6. Interpretation consistent with Bill of Rights to be preferred -

Wherever an enactment can be given a meaning that is consistent with the rights and freedoms contained in this Bill of Rights, that meaning shall be preferred to any other meaning.

Even though the legislature chose the words "rights and freedoms contained in [the] Bill of Rights", section 6 is generally understood as requiring a meaning "consistent with the Bill of Rights" to be preferred. Examples of this approach can be found in the judgments of Thomas J in Quilter v Attorney General: ${ }^{22}$

This Court has an interpretative role and while it must, in accordance with Parliament's direction prefer a meaning to any statutory provision which is consistent with the Bill of Rights, it cannot adopt a meaning which is clearly contrary to Parliament's intent.

Hammond J in Jeffcoat $v$ Waetford: 23

... the words actually used will be read very strictly, and wherever possible consistently with the New Zealand Bill of Rights Act 1990.

And Gault J in $R$ v Poumako: ${ }^{24}$

The direction is that wherever a meaning consistent with the Bill of Rights can be given, it is to be preferred.

Similarly, throughout the (limited amount of) legal writings on the meaning, operation, and effect of section 6, it is evident that the phrase "consistent with the rights and freedoms contained in this Bill of Rights" as found in the Act is predominantly equated with the

21 The "rule of interpretation" for the New Zealand Bill of Rights Act 1990 derives from Ministry of Transport v Noort [1992] 3 NZLR 260, 266 (CA) Cooke P (as he then was).

22 Quilter v Attorney-General [1998] 1 NZLR 523, 541; (1997) 16 FRNZ 298, 317 (CA) Thomas J.

23 Jeffcoat $v$ Waetford (1999) 17 CRNZ 75, 76-77 (HC) Hammond J.

$24 R v$ Poumako [2000] 2 NZLR 695, 703 (CA) Gault J (as he then was). 
phrase "consistent with the Bill of Rights". An example is the following excerpt from an article in the Auckland University Law Review: ${ }^{25}$

[T] here can be no doubt that section 6 has the following effect: where a statutory provision has more than one express meaning and one of those meanings is consistent (or more consistent) with the Bill of Rights, the Courts must prefer that meaning.

Three pages later the author quotes the judgment of Gault $\mathrm{J}$ in the case $R v$ Poumako by stating: 26

The meaning to be preferred is that which is consistent (or more consistent) with ... the Bill of Rights.

It is not difficult to guess what has been omitted in this quote. The judgment actually reads "consistent (or more consistent) with the rights and freedoms in the Bill of Rights";27 even though two sentences later - as has been mentioned above - Justice Gault uses the "abbreviated" version in referring to section $6 .^{28}$

A similarly imprecise quote can be found in a British article on section 3(1) of the British Human Rights Act 1998, which is comparable to section 6 of the Bill of Rights Act: ${ }^{29}$

Section 3(1) resembles s 6 of the New Zealand Bill of Rights Act [1990], which says that "wherever an enactment can be given a meaning that is consistent with [the Bill of Rights] that meaning shall be preferred to any other meaning".

Finally, as a last example, Paul Rishworth states in his commentary to the Bill of Rights Act that: ${ }^{30}$

[s]ection 6 requires meanings to be given which are "consistent" with the Bill of Rights ... A law which prescribes a reasonable limit on a right is "consistent" with the Bill of Rights. Only when a law imposes unreasonable limits could it said to be inconsistent.

25 Michael Hodge "Statutory Interpretation and Section 6 of the New Zealand Bill of Rights Act: A Blank Cheque or a Return to the Prevailing Doctrine?" (2000) 9 AULR 1, 9.

26 Hodge, above, 12

27 Poumako, above, 703, Gault J.

28 See footnote 23 above. Poumako, above.

29 Francis Bennion "Section 3(1) of the Human Rights Act 1998" (1999) 163 JP 984.

30 Paul Rishworth in Sir Francis Boyd and James Robertson (eds) Adams on Criminal Law (Brookers, Wellington, 1992) para 10.4.06. Also compare with Janet McLean, Paul Rishworth, and Michael Taggart "The Impact of the Bill of Rights on Administrative Law" in New Zealand Bill of Rights Act 1990: Papers Presented at Seminars Held by the Legal Research Foundation at Auckland on 24 August 1992 and Wellington on 25 August 1992 (Legal Research Foundation, Wellington, 1992). 


\section{B What this General Understanding of Section 6 Means}

When using the phrase "consistent with the Bill of Rights" in the context of section 6, judges and legal scholars interpret the provision as requiring Courts to adopt such meaning of an enactment (if possible) that is consistent with the Bill of Rights as a whole especially with section $5 .{ }^{31}$ The latter section provides:

\section{Justified limitations -}

Subject to section 4 of this Bill of Rights, the rights and freedoms contained in this Bill of Rights may be subject only to such reasonable limits prescribed by law as can be demonstrably justified in a free and democratic society.

This means, as already alluded to in the citation from Rishworth's commentary, that an enactment limiting a right or freedom affirmed by the Bill of Rights, but where that limit is reasonable, prescribed by law, and demonstrably justified, it is nevertheless considered to be "consistent" for the purposes of section $6 .{ }^{32}$ Consequently, the approach allows a "rightsrestrictive" interpretation to be adopted by virtue of section 6 .

\section{The Effect on Interpreting Empowering Provisions}

In the context of subordinate legislation, the approach to section 6, above, has the effect that in determining whether a limitation contained in subordinate legislation is ultra vires the empowering provision, section 5 is applied to the subordinate legislation. Since the empowering provision (absent express language to the contrary) is interpreted only to not authorise limitations inconsistent with the Bill of Rights, that is, inconsistent with section 5, any limitation in subordinate legislation that passes the test of section 5 is considered to be intra vires. What effectively happens is that the empowering provision and the limitation contained in the subordinate legislation are merged and assessed conjunctively under section 5 . This approach is summarised by Rishworth who concludes: ${ }^{33}$

Assuming no [express or necessarily implicit] provision to the contrary, delegated legislation which is inconsistent with the Bill of Rights can be argued ... to be ultra vires. In such cases, in order to demonstrate that the delegated legislation is inconsistent with the Bill of Rights, it will be necessary to consider s 5 (for the legislation may perhaps be justified as a reasonable limit within the terms of that section ... ).

31 Hammond J makes this very clear in Jeffcoat $v$ Waetford (1999) 17 CRNZ 75, 76 (HC) by using the expression "consistent with the New Zealand Bill of Act 1990" which unequivocally refers to the whole Act.

32 See above approach by Rishworth in Adams on Criminal Law, above.

33 Adams on Criminal Law, above. 
Going back to the example of the permit requirement in the Wellington City Council Bylaw: Since the "blanket" permit requirement could arguably be considered a reasonable limit of the right to freedom of assembly that is prescribed by law and demonstrably justified in a free and democratic society, it would not - under the "consistent with the Bill of Rights as a whole" approach - be ultra vires the broad empowering provisions of the Local Government Act 1974.

\section{A DIFFERENT APPROACH TO INTERPRETING SECTION 6}

The "consistent with the Bill of Rights as a whole" approach, however, seems to skip the question whether or not the limitation as such is within the scope of the empowering provision. In the final part of this paper, the proposition will be advanced that a different approach could be taken to interpreting and applying section 6 to empowering provisions. The approach would enable courts to legitimately redress the situation that fundamental rights and freedoms such as the right to freedom of peaceful assembly are extensively limited through subordinate legislation without sufficiently clear statutory authorisation. This, of course, presupposes that such redress would, in fact, be considered desirable. While there are certainly considerable practical reasons against the immediate implementation of such an approach, such reasons do not per se render a change in the way legislation is made undesirable.

\section{A Focussing on "Rights and Freedoms"}

A first indication of different possible interpretations of section 6 can be found in Ministry of Transport (MOT) $v$ Noort where Cooke P (as he then was) expressed the view that: ${ }^{34}$

... the question under s 6 [might be] whether a meaning consistent with those rights and freedoms is open, not whether a meaning consistent with the Bill of Rights as a whole is open.

Based on this, the proposition is advanced that the phrase "consistent with the rights and freedoms contained in the Bill of Rights" should be construed as referring (if permitted by the language of the statute) to rights and freedoms in their entirety, rather than in a form limited by section 5 . As Cooke P also noted in Noort: ${ }^{35}$

[t] he scheme of the Act seems to be that the rights and freedoms are declared in broad language in Part II and that their relevance in New Zealand, including the circumstances in which they may be subject to limits, is dealt with in Part I. In other words the rights and freedoms have been treated by Parliament as different from the justifiable limits.

34 Ministry of Transport v Noort [1992] 3 NZLR 260, 273 (CA) Cooke P.

35 Noort, above. 
The approach that an interpretation should be consistent with the rights and freedoms contained in Bill of Rights would therefore specifically prefer (if possible) such meanings in the first place that do not include justified limitations. In other words, where a meaning of an enactment can be ascertained that does not in any way (not even justifiably) impinge on the rights and freedoms, such a meaning should be adopted.

\section{B Whether the Approach is Correct}

The question is, however, whether it would be correct to adopt such an approach. A first argument in favour can be seen in the fact that the wording of section 6 expressly states "consistent with the rights and freedoms contained in this Bill of Rights" and not "consistent with this Bill of Rights". The heading to section 6, however, uses the phrase "consistent with Bill of Rights". Based on this it seems possible that the legislature intended the two phrases to be used interchangeably. This impression is reinforced by a similar pattern of phrases found in section 7 and the heading thereto. However, when looking at sections 4 and 7, it becomes clear that an interchangeable use of the two phrases would be contrary to the statutory scheme of the Bill of Rights Act.

First, section 4 employs the words "inconsistent with any provision in this Bill of Rights". The reason why Parliament did not choose the wording "inconsistent with the rights and freedoms" must have been that it specifically wanted section 4 to cover any inconsistencies remaining after the application of section 5 . This demonstrates that Parliament was well aware of a difference in meaning between "rights and freedoms" and "the Bill of Rights" as a whole. ${ }^{36}$

Secondly, the phrase "rights and freedoms" can also be found in section 7 which requires the Attorney-General to report to Parliament any inconsistency of a Bill that is introduced which appears to be inconsistent with the rights and freedoms contained in the Bill of Rights. Although the Attorney-General also interprets this phrase as meaning "inconsistent with the Bill of Rights", that is, inconsistent with section 5, strong arguments have been advanced that this, too, is the wrong test under section 7 of the Bill of Rights Act. $^{37}$

Thirdly, although section 6 of the Bill of Rights Act constitutes a rule of interpretation, it is - maybe surprisingly, but consequently - itself subject to other rules of interpretation, in particular section 5(1) of the Interpretation Act 1999: Well-Intentioned Nonsense" (1992) 22 VUWLR 135. 


\section{Ascertaining meaning of legislation -}

(1) The meaning of an enactment must be ascertained from its text and in the light of its pupose.

The general purpose of section 6 can be seen as giving as much effect as possible to the rights and freedoms contained in the Bill of Rights. ${ }^{38}$ It consequently mandates a rightscentered rather than a rights-restrictive approach.

In conclusion, it can therefore be said that to prefer meanings consistent with the rights and freedoms in their entirety is a justified and warranted interpretation of section 6.

\section{The Effect on Interpreting Empowering Provisions - Practical Implications}

To adopt the above proposed approach to interpreting and applying section 6 would lead to the result that overly broad empowering sections would have to be given a meaning consistent with the rights and freedoms contained in the Bill of Rights in their entirety. Put in plain terms, such empowering provisions would simply be held not to authorise any abrogation of a right or freedom whatsoever. As has been mentioned above, this would require the legislature to either regulate itself matters found ultra vires in subordinate legislation or to pass more express empowering provisions. The principle of parliamentary responsibility for fundamental rights and freedoms would thereby be given substantial effect. It should be noted, however, that considering the generality of most empowering Acts in New Zealand, this approach would render a large number of regulations ultra vires "overnight". On the other hand, even under this approach to section 6 , the courts would nevertheless be left to decide whether an empowering provision is actually too broad to support a limitation contained in a regulation.

\section{Reconciling the Approach with MOT v Noort}

The approach to prefer a meaning consistent with the rights and freedoms in their absolute form might be incompatible with the judgment of the Court of Appeal in Noort. Although Justice Hardie Boys suggested that: ${ }^{39}$

[s]ection 6 is directed to the meaning of the other enactment, and does not permit any limitation or qualification of the Act's rights and freedoms. It rather treats them as absolutes, and so, on its own, could allow quite wide scope for the application of s 4 .

All members of the Court seemed to agree that an interpretation should be adopted that upheld a right or freedom in a limited form ${ }^{40}$ - either by application of section 5 (as

38 Compare generally with Noort, above, 287, Hardie Boys J.

39 Noort, above.

40 In Noort, above, Gault J dissented on the facts. 
per Richardson J, Hardie Boys J, and McKay J) or by inherently limiting the right or freedom to a "reasonable" right or freedom (as per Cooke P and Gault J). ${ }^{41}$

However, in Noort the Court of Appeal approached the relationship of sections 6, 5, and 4 from a slightly different angle. The question there was whether the Bill of Rights Act actually allowed a statute to be given a meaning that was only consistent with the rights and freedoms in an abridged form when an interpretation consistent with the rights and freedoms in their entirety was not possible. The Crown's argument seemed to have been that where an enactment cannot be interpreted consistently with the full rights and freedoms, the court is precluded from ascertaining a meaning "in the middle" consistent with the rights and freedoms in at least some acceptably limited form. Rather, the rights and freedoms in question should be held to be excluded by virtue of section 4 . The Court was not prepared to accept this argument. As Hardie Boys J explained: ${ }^{42}$

[t] here must be many a statute which can be read consistently with the Act's rights and freedoms if it is accepted that the statute has imposed some limit or qualification upon them; in other words, that although the statute cannot be given a meaning consistent with the Act's rights and freedoms in their entirety, it can be given a meaning consistent with them in a limited or abridged form. It is obviously consistent with the spirit and the purpose of the Bill of Rights Act that such a meaning should be adopted rather than that [section] 4 should apply so that the rights and freedoms are excluded altogether. Section 5 in my opinion is designed to enable such an approach to be taken.

The reason why the approach advanced in this paper does not contradict Noort is that it is confined to situations where a statute can be given a meaning consistent with the Bill of Rights Act's rights and freedoms in their entirety because the empowering provision is overly broad. Where this cannot be done, that is, where an empowering provision can only be interpreted to allow the full rights and freedoms contained in the Bill of Rights to be limited through subordinate legislation, the reasoning consequently does not apply. However, even that would be consistent with the overarching theory that Parliament should be responsible for dealing with issues concerning fundamental rights and freedoms. If Parliament clearly expresses in an empowering provision how a certain right

41 Compare this with the judgment of Cooke P in Noort, above, 274, where His Honour stated:

There is no solid ground for inferring that the administration of the Transport Act will be substantially impaired or the road toll substantially reduced by the time required to give drivers who have been duly brought in for further tests, usually after a positive breathscreening test, a limited opportunity of making telephone contact with a lawyer and taking advice. (emphasis added).

42 Noort, above, 287, Hardie Boys J. 
or freedom may be abrogated through subordinate legislation, Parliament will meet this responsibility.

\section{CONCLUSION}

The New Zealand legislature in 1990 chose to adopt a version of the Bill of Rights that did not give the judiciary the power to strike down legislation incompatible with the Bill of Rights. One of the reasons for doing so was that the protection of fundamental human rights was believed to be best left in the hands of the Parliament. If it was - and presumably still is - indeed one of the major concerns that Parliament is the proper body for safeguarding human rights in New Zealand, this principle should not be applied halfheartedly. At present, both the executive branch of Government and subordinate legislative bodies enjoy a variety of broad discretionary powers used to limit fundamental human rights even though Parliament has not addressed whether such limits should be made. Although these limits will in most cases comply with section 5 of the Bill of Rights Act they are nevertheless outside the control of Parliament (leave aside the powers of Parliament under the Regulations (Disallowance) Act 1989). An example of such lack of control is the fact that using broad empowering provisions to restrict rights and freedoms through subordinate legislation is not subject to the supervision of the Attorney-General under section 7 of the Bill of Rights Act.

Implementing a "principle of substantiality" in New Zealand along the lines outlined in this research paper would mean facing considerable practical problems. A significant number of regulations and bylaws (I hesitate to say that it would be the majority) would be ultra vires. As a consequence, Parliament would have to change the way primary legislation is drafted - which is the whole point behind applying a theory of parliamentary responsibility for fundamental rights and freedoms. Impracticability should, however, not deter from the conclusion that gradually shifting towards an increase of parliamentary responsibility for issues involving fundamental rights and freedoms would, in principle, be desirable for the enhancement of human rights protection in New Zealand. 